Marquette University

e-Publications@Marquette

$1-1-1987$

The Case for and against Televised Political Advertising: Implications for Research and Public Policy

Gene R. Laczniak

Marquette University, eugene.laczniak@marquette.edu

Clarke L. Caywood

Marquette University

Published version. Journal of Public Policy and Marketing, Vol. 6, No. 1 (1987): 16-32. Stable URL. C) 1987 American Marketing Association. Used with permission. 


\section{AMERICAN MARKETING \\ ASSOCIATION}

The Case for and against Televised Political Advertising: Implications for Research and Public Policy

Author(s): Gene R. Laczniak and Clarke L. Caywood

Source: Journal of Public Policy \& Marketing, Vol. 6 (1987), pp. 16-32

Published by: American Marketing Association

Stable URL: http://www.jstor.org/stable/30000152

Accessed: 10-05-2017 14:03 UTC

JSTOR is a not-for-profit service that helps scholars, researchers, and students discover, use, and build upon a wide range of content in a trusted digital archive. We use information technology and tools to increase productivity and facilitate new forms of scholarship. For more information about JSTOR, please contact support@jstor.org.

Your use of the JSTOR archive indicates your acceptance of the Terms \& Conditions of Use, available at http://about.jstor.org/terms

American Marketing Association is collaborating with JSTOR to digitize, preserve and extend access to Journal of Public Policy \& Marketing 


\title{
The Case For and Against Televised Political Advertising: Implications for Research and Public Policy
}

\author{
Gene R. Laczniak \\ Clarke L. Caywood
}

Presented here are the advantages and disadvantages of using the increasingly controversial tactic of televised political advertising. An agenda for needed research to shed light on this issue is put forward, along with an articulation of several public policy options for adjusting the existing process.

Gene R. Laczniak is a Professor of Business and Clarke L. CAYwood is an Assistant Professor of Marketing, both at the College of Business, Marquette University, Milwaukee, Wisconsin 53233.
Background Concerning Televised Political Advertising
The use of television advertising to help conduct political campaigns has been increasing enormously. As one researcher noted, "At least in terms of dollars spent, advertising has become a dominant force in the political marketplace during the past 25 years" [Rothschild 1978]. This is a profound development for marketers, particularly those concerned with the social ramifications of marketing, because it focuses attention upon how one very visible promotional strategy-the political TV ad-might greatly influence the country's fundamental political process. Concerning this trend, Steven Roberts [1986], who covers Congress for The New York Times wrote:

When voters cast their ballots . . . they will be making choices based largely on impressions created by media consultants. Marshall McCluhan was right: the medium is the message. In American politics today the medium is television, and that medium is dominated by an elite of highly paid but unelected consultants. The democratic ideal of a candidate talking directly to the voter and appealing for support has been profoundly distorted.

This paper seeks to develop the following points.

1. The social and legal elements of the case for and against the increasing use of political TV advertising;

2. How the published advertising, marketing, and communications research supports or does not support these arguments for and against political TV advertising.

3. What research questions should be answered in order for academicians and public policy analysts to begin moving toward more definitive judgments about the impact of political TV advertising; and,

4. What public and private policy options are available to regulate or control televised political advertising.

There is little doubt that televised political advertising is increasing and growing more controversial. In a report quoted in the Wall Street Journal [1986], the Citizens Research Foundation estimated that the 1986 Congressional elections involved expenditures of about $\$ 350$ million on advertising. This constituted a 71 percent increase over the previous mid-term election of 1982. In addition, it was noted that most of the money went to television, primarily for 30 -second spotssometimes called "polispots." Advertising Age, the weekly trade magazine of the ad 
industry, reported an even higher figure of $\$ 450$ million spent in 1986 by candidates for Congressional and Senate seats. Note, for purposes of comparison, that this amount, spent in a compressed period of time, approached Pepsico's 1985 advertising budget of $\$ 473$ million. In addition, many of these millions of dollars were spent on so-called negative advertising which one researcher [Merritt 1984] has defined as "advertising which identifies a competitor for the purpose of imputing inferiority."

These developments of increasing and often negative TV political advertising have provoked a substantial outcry. Historian Arthur Schlesinger, Jr. [1986] has suggested that television advertising has resulted in "the transformation of the electorate into an audience of passive spectators." And well-known political columnist James Reston called the 1986 political campaigns "a disgrace . . . because all too often they were devoid of self control and became mere clashes of money, personality, negative television ads, and other dirty tricks." Despite all of the spending on advertising, voter turnout was only 37 percent, the lowest percentage of eligible voters since 1942. This 1986 turnout represented a 12 percent drop-off in voter participation from the prior 1982 mid-term election [Taylor 1986]. Perhaps the low turnout was because the ' 86 campaigns were characterized by some of the dirtiest mud slinging in the history of politics. Collectively, these events have led to a call for a revised and renewed attempt to legislate controls over TV political advertising. The expectation is that after hearings in the 100th Congress (1987), Senators John Danforth (R., Mo.) and David Boren (D.,Ok.) will eventually introduce separate legislation to regulate political advertising.

One issue at question from the standpoint of macromarketing is whether the increased incidence of political advertising on television is a positive development. The discussion of this question has major ramifications for marketing simply because raising the issue focuses attention on the general relationship between television advertising and society. Thus, any actions which are taken to regulate political advertising may set precedents for the regulation of commercial advertising. However, whether the above inference is accurate or not, the level of expenditures for political advertising and the increased usage of marketing consultants in political campaigns make this issue worth carefully examining.

\section{The Case for Televised} Political Advertising

First Amendment Protection
Perhaps the strongest point in favor of the growth of TV advertising in conducting political campaigns is that it is a form of free speech, subject to First Amendment protection. In this sense, political advertising is the contemporary version of the whistle-stop campaign rally, the stump speech, or the townhall debate. Where local jurisdictions or courts have attempted to regulate the content of political advertising, the higher courts have been quick to set such interference aside [Wilson $v$. The Superior Court of Los Angeles County 1975, Vanasco v. Schwartz 1976, Postel v. Schwartz 1976]. On the other hand, Harvard legal scholar Laurence Tribe [1978] noted that a number of state and local laws exist which "uphold some restrictions on campaign practice. . . . Few cases have addressed the constitutionality of such statutes . . . " [p.798]. In general however, it is most useful to note the language used by the U.S. Supreme Court in their Mills v. Alabama [1966] ruling where they wrote:

Whatever differences may exist about the interpretations of the First Amendment, there is practically universal agreement that a major purpose of that amendment was to protect the free discussion of governmental affairs. This, of course, includes discussions of candidates ... and all such matters relating to political processes. 
As further evidence for the sanctity of political speech one only need look at Section 315 of the Federal Communications Act of 1934 which suggests that while broadcasters may defer from airing a product commercial which they feel is deceptive or misleading, they do not have the same freedom in reviewing and refusing political advertisements. As the Supreme Court noted in New York Times v. Sullivan [1964] political speech should be "uninhibited, robust, and wide open . . . " Thus one is left with the unmistakable position that political advertising is held to be a sacrosanct form of marketing communication, different from commercial speech, because it is an embodiment of political free speech protected by the First Amendment.

The Contemporary Method of Campaigning
A second general point in favor of TV political advertising is that it is highly consistent with the corporate strategy approach to the management of contemporary political campaigns. Journalist Sidney Blumenthal [1980] who has written extensively on modern campaign tactics basically perceives political candidates as developed, packaged, distributed and promoted in the same fashion as many economic commodities. To him, the process evokes the question, "can political candidates be sold like soap?" and the answer is "yes." He grudgingly grants the effectiveness of transferring commercial promotional techniques to the political arena and has observed ". . . television commercials and media appearances serve as the new mobilizers of voters." And in a New York Times article, he commented more cynically, "the (advertising) campaign method of governing implies a vision of voters as passive yet movable; supportive of bold action, yet possessing shallow allegiances; willing to endorse new possibilities yet afflicted with a short attention span" [Blumenthal 1981]. Put another way, heavy use of TV political advertising is the present and likely future method of conducting an up-to-date political campaign. This argument for the efficiency and effectiveness of TV political advertising has several subpoints including the following:

1. TV is important in cultivating a positive candidate image. A distinct TV media presence is an attribute that serious political candidates of the 1990s must develop and nurture. President Reagan is a prime example. He has been dubbed the "Communicator-inChief" by numerous members of the media. Blumenthal [1980] has noted that President Reagan's success can be best attributed to carefully crafted television commercials and dramatic media appearances rather than the intricate political connections with party members that had been necessary for political power and success in the past.

2. Television is the central communications channel of our time. TV advertising is the key medium for reaching the current generation of adult Americans, including the populous baby boomers - the first TV generation. According to some, this group is attuned to receiving its messages in the 30 second bursts of information that have been made so popular by television commercials. As Engel et al. [1986] note in the popular textbook on promotional strategy, the medium of television enjoys tremendous popularity and believability among the American public. One empirical study [Atkin and Heald 1976] has shown that exposure to political television ads is correlated with increased candidate liking, platform knowledge, and interest in the general campaign. Admittedly, these findings were based on a single telephone study which analyzed a 1974 Congressional race between nonincumbents in the state of Michigan.

3. Television reaches voters quickly and with impact. Implicit in the growth of political TV ads is the contention that television advertising is also an efficient medium for reaching voters in a short period of time. Certainly, constituencies have grown over the years and television advertising speeds the flow of information to voters thereby supposedly promoting an exchange of views concerning the issues and the candidates. Of course, this assumes that the televised advertisements deal with issues, something some political observers increasingly doubt. One researcher [Joslyn 1980] drawing a convenience sample of 156 political ads from the archives of a prominent Washington, D.C. consulting and public relations firm, reported that half of the political ads analyzed contained specific information about the characteristics of the candidate and about 20 percent of the ads content analyzed contained specific information about the candi- 
dates' position on issues. Joslyn [1980] drew the conclusion that televised political ads were more information rich than many people supposed. Also of note here is Arterton's research [1984] on the primary influence of the news media in the early phases of a campaign which suggests that television advertising may increase news coverage of a campaign by making it appear more newsworthy.

The Motivation of Voters

The Case Against Televised Political Advertising

Image, not Issues
TV political advertising is also thought to vitalize voters who otherwise might not participate in a political campaign. This element of the argument is consistent with the notion that the modern style of campaigning should leave no stone unturned. Whether, in fact, TV political advertising can move potential nonvoters or undecided voters "off the fence" and get them to vote in a political campaign is a critical matter requiring future research. The limited amount of study that has been done on this topic is not particularly supportive of this view. For example, Rust, Bajaj, and Haley [1984] studied the advertising used in the 1982 Texas gubernatorial election and found no relationship between television viewing of any kind and voter participation.

In an earlier, and somewhat methodologically questionable study, Kaid [1976] utilized self-report data from personal interviews conducted prior to a statewide race in Illinois. She found that respondents claimed that exposure to television advertising had little influence on their ultimate voter choice. Mulder [1979] using telephone interviews in a pre-post survey of Chicago voters during the 1975 mayoral campaign, found the effect of TV spots to be about the same upon involved and noninvolved voters. This conflicts with the findings of Rothschild [1978] and Palda [1975] from earlier empirical studies. It must be recognized that much of the research on the effectiveness of political communications is driven by the contingencies which are being investigated. For example, Palda [1975] and Rothschild [1978] concentrated on involvement level, Graber [1980] focused on news coverage and Reid and Soley [1983] as well as Jacobson [1978] conclude that the effectiveness of advertising is a function of campaign qualities, such as expenditure levels. Thus the effect of advertising upon voter participation requires further study to clear up these discrepancies and to identify and rank order the important intervening variables especially in light of the lower voter turnout in recent elections.

One of the strongest arguments against the increased use of TV political advertising is that it trivializes the complexity of the issues. Because of the nature of the medium, it is believed by many casual observers that this practice accelerates the tendency of one issue or limited issue campaigns. At its worst, TV advertising is thought to accentuate the importance of candidate image at the expense of providing information to the public concerning candidate substance. Schlesinger [1986] writes that "Television is the major reason . . . for the decay of political debate into commercial spots that encourage negative rather than positive argument." And as Ed Blakely, the communications director of the National Republican Congressional Committee, has been quoted, "Its image that sells. The substance is not worth a damn out there" [in Latimer 1985].

The limited empirical information which exists concerning this view is quite ambivalent. For example, Elebash and Rosene [1982], using content analysis to study all media advertising run during the 1978 Alabama gubernatorial race (including the primaries) conclude what most would expect: that newspaper ads contain 
more issues than broadcast media advertisements. Other descriptive research on the "issues vs. image" debate found that emphasis upon developing issues varied with the level of the election [Bowers 1972; Humke, Schmitt and Gupp 1975]. Hofstetter and Zurkin [1979] surprisingly concluded that political TV ads contained more issue information than the network news which tended to emphasize "campaign hoopla." Also, with respect to televised political advertising specifically, a study by Faber and Storey [1984] which used telephone interviews prior to the 1982 Texas Governors' election, concluded that recall from television advertising was generally low and that when recollection did take place it was as likely to include issue information as image type information. These authors also noted that a content analysis of the advertising used during the campaign indicates that both image and issue material were used in a relatively balanced fashion. The low recall in this campaign was a particularly provocative finding as the contest was characterized by especially high expenditures on TV advertising. One candidate, incumbent Gov. Bill Clements, was spending $\$ 280,000$ per week on television advertising and wanted to spend much more but the Texas television stations refused to carry additional spots [Rust et al.1984].

In an older study, Atkin et al. [1973] studied Governors' campaigns in the states of Wisconsin and Colorado during the 1970 elections. They based their findings on 516 telephone interviews prior to election day, concluded that candidate qualifications and issue oriented positions were more widely learned than personality characteristics and "softer" information concerning candidate image. Similarly, Joslyn [1980] found that 20 percent of the spot ads analyzed from political archives contained specific information on positions and half of the advertising contained information about characteristics of the candidate. Finally, Latimer [1985] exhaustively content-analyzed state and federal elections in Alabama in 1978, 1980, 1982, and 1984. Based on her research, she concluded that while personal characteristics (i.e. image) were more prevalent than policy or issue information, differences between the two general approaches (in terms of frequency of use) were not that great. Moreover, for state elections (particularly the governors' office) winners of elections tended to develop more policy-related issues than image-oriented, personal characteristics. This relationship did not hold true for federal elections where the development of personal characteristics and policy issues was about the same. In short, exactly what image-oriented TV advertising does to the flow of information in a political campaign still remains to be determined.

Overly Negative A second general set of arguments against the growing incidence of televised political advertising has to do with the notion that TV political ads are overly negative in their approach. This argument has several variations including the thesis that TV political advertising often places a premium on negative, emotional appeals thereby subverting the ideal of rational voter choice. Histories of campaign practices have of course noted that negative promotional attacks have been parcel of the American political tradition since Colonial days. Current criticisms add that too much TV political advertising is "negative" [Sabato 1981 reports that about one-third of commercials are and that the percentage is growing] and that much of negative advertising may also be unethical. Does this line of reasoning have merit? Certainly negative advertising-ads which attack opponents-is being used more often; it dominated at least six campaigns in the 1986 Senate elections [Taylor 1986].

The 1986 Wisconsin Senatorial campaign between incumbent Republican Robert Kasten and Democratic challenger Ed Garvey, a former NFL Players Association Director, is a prime illustration of what some see as a growing practice. In a campaign that the USA Today [1986] characterized as "slime slinging," Kasten spent $\$ 2.9$ million and Garvey $\$ 1$ million mostly on negative TV advertising. 
Garvey's ads attacked Kasten's late income tax filings, his alleged drinking and driving problems, and his business deals. Kasten's ads focused on Garvey's purported character defects, his blind ambition, and his mismanagement of union funds. The end result was a libel suit filed by Garvey against Kasten (still pending) and a Wisconsin electorate wondering, "why can't we do better?"

However, once again what limited empirical information exists about negative and image advertising is decidedly mixed. Garramone [1984], using telephone information in a state of Michigan district prior to a 1982 Congressional election, concludes that the most common effect of negative political advertising for those who recall seeing such ads is a backlash against the sponsor of such advertising. Meadow and Sigelman [1982], employing experimental methods with customdesigned sample advertisements, conclude that image-oriented spot advertisements are no more effective than other kinds of informational appeals in terms of generating candidate credibility and attractiveness. Yet Patterson and McClure's [1973] early research on political ads found attitude and belief changes did occur among viewers of negative ads in the 1972 Presidential campaign.

Certain aspects of the unfortunate growth of negative advertising seem to have merit. Clearly, in terms of dollars spent, the reliance of candidates upon political TV advertising is increasing. The very nature of the 30 -second television spot does not allow for a great deal of substantiation regarding charges that might be made about an opponent. As Sabato [1981] has written, "Campaigning seems to have degenerated into personality cults and the incessant search for star quality, name recognition, malleability, and media 'sensibility.' The obvious result is the replacement of work horses with show horses-politicians who enjoy running to the exclusion of governing (p.322)."

Voter Turnoff A third argument against political advertising on TV has to do with the impact of televised political advertising, especially negative ads, upon voter turnout and voter skepticism. In 1986, despite the massive amount of money spent on televised political advertising, the voter turnout of 37 percent was the lowest since 1942. Voter participation was especially low in campaigns that were characterized by intensely negative advertising. The Wisconsin Senatorial campaign mentioned earlier was a case in point where, amazingly, 31,600 fewer people voted than in the less negative election for Governor. As Steven King, the chairman of the Wisconsin Republican Party, remarked when asked whether the negative tone of the campaign contributed to the unwillingness of individuals to cast a ballot in the Wisconsin Senatorial campaign, "I know of no other explanation" [Katz 1986]. And as one political consultant observed about the 1986 elections, "in a campaign of negative ads fighting negative ads, what incentive is there for the viewer to go to the polls? Obviously, both these candidates are turkeys. The potential voter is left with a disgruntled sentiment that it's a shame someone has to win" [O'Leary/Kamber Report 1986].

The impact of negative advertising upon voter behavior is an area which is in desperate need of additional study. In one of the few efforts to specifically analyze the effect of negative political advertising, Merritt [1984] charted the reactions of 314 adult age voters in a telephone survey to the advertising (mostly negative) which occurred in a 1982 state of California Assembly race. Using self-report information, Merritt concluded, "the results indicate that negative political advertising evokes a negative effect toward both the targeted opponent and the sponsor" (p.37). In contrast, Patterson and McClure [1973] found the negative advertising by Nixon against McGovern was effective in changing voter beliefs and attitudes.

Future efforts to establish the precise impact of negative advertising upon voting behavior certainly needs to be undertaken in a variety of political settings and races. Variables which need to be controlled because of their intervening nature include 
Table 1. Suggested Research Agenda for Understanding the Role of Televised Political Advertising

Topic

(1) Negative political advertising

(2) The ethics of political advertising on TV

(3) Public reaction to political ads on TV

(4) Effectiveness of televised political advertising

(5) The influence of televised political ads upon voter information

(6) The ultimate success of TV's political ads

(7) Involvement and televised political advertising

(8) TV advertising and voter participation

(9) Regulation of political ads on TV

(10) Conditions increasing the usage of political TV ads
Research Question Subject Group/Data Base

Random sample (national or regional) of TV ads for national political campaigns cal ads are "negative," i.e. disparaging of the opponent?

What percentage of TV political ads are "unethical"?

(same as above)

What is the prevailing public opinion of the increased usage of televised political ads?

Are TV ads more effective than other forms of political communication? Are "negative" political ads more effective than positive political advertising?

Are political campaigns which are dominated by TV ads decided on fewer issues than are comparable political contests?

What is the relationship between money spent on televised political advertising and success (i.e. candidate election)?

Are political ads on TV more effective in high or in low voter involvement campaigns?

Can TV political ads significantly influence (positively or negatively) voter participation in a campaign?

How might political advertising be meaningfully regulated?

What is the relationship among environmental variables, intensity of political TV ads, especially negative ads, and election success?
National opinion poll (longitudinal)

Subject panel matched demographically to voter population

Mail survey of voters

Exit interviewing at polls

Public records

Survey of voters and nonparticipating registered voters

Surrogate voters (i.e. subjects in behavioral lab)

Legal, political, and broadcasting experts

Perceptions of experts and public records
Content analysis of ads

Content analysis of ads with political \& ethical experts as judges

Telephone or mail survey

Laboratory research design with control plus information processing approach

Survey plus analysis of press coverage of campaign

Analysis of campaign expenditure statements, plus measures of candidate awareness and preference (pre- and postcampaign), controlling for type and amount of advertising

Questionnaire

Laboratory research/design with control

Focus group, Delphi analysis of legal precedents

Multiple regression or causal modeling with valid indices of environmental factors 
voter involvement [Rothschild 1978], candidate incumbency [Graber 1976], as well as the level of campaign expenditures for advertising both on an absolute and relative basis [Soley and Reid 1982]. Given the increasing use of television as a primary communications strategy, some of the avenues of research suggested later in this paper [See Table 1] may shed light on some of these issues. Interestingly, Roger Stone, a political consultant, noted recently in Advertising Age [Colford 1986], "voters will tell you in focus groups that they don't like negative ads, but they retain the information so much better than positive ones. The point is: people like 'dirty,' why (else) do tabloids sell?"

Ethically Dubious

A fourth and more systemic reason for curtailing the use of televised political advertising is that, because of its advocacy nature, political advertising damages the reputation of all marketers by reinforcing the notion that they are hired guns. Hill [1984] writes that many of the most respected advertising agencies have become reluctant to accept political candidates as clients for financial and ethical reasons. Laczniak, Lusch, and Strang [1981], using a quasi-experimental design to ascertain whether there were different ethical overtones perceived in the marketing of different products, found that indeed ethical evaluations are product dependent. Of particular note was their finding that ethical concerns were more substantial for social issues (such as a political candidate) than for the marketing of traditional economic goods. Surlin and Gordon [1977], quite interestingly, found political ads which attacked opponents to be perceived as both more informative and more unethical by voters of high education/high socioeconomic status when compared with those with mid-socioeconomic status. In a related research article [1976] they wrote that future research, " . . . might also explore the information-ethics tradeoff by way of the advertising industry's perceived need for some code of conduct" [p. 98]. In contrast, O'Keefe [1980], analyzing the 1976 President election in one Ohio county, found that voters who rely heavily on political information gleaned from television did not have any increased dissatisfaction with the political system. Further investigation of such questions is necessary as the role of advertising increases in its import to the political process. Were Laczniak, Lusch, and Murphy [1979] alarmist when they wrote:

As social marketing efforts increase, large segments of the public may not distinguish between controversial topics being marketed and the tools used to promote them. This could lead to marketers being perceived as the "neo-propagandists" of our societyhardly a positive public badge for the discipline of marketing to wear (p. 34).

Perhaps the final word on this point should go to David Ogilvy, one of the most respected elder statesmen in the field of advertising, who has never permitted his own agency to hold the account of a political candidate. Ogilvy has long maintained that political campaigning is prone to chicanery and that most political advertising is "flagrantly dishonest" and may lead to negative consequences for all advertising professionals. Ogilvy has written:

In a period when television commercials are often the decisive factor in deciding who shall be the next President of the United States, dishonest advertising is as evil as stuffing the ballot box. Perhaps the advertising people who have allowed their talents to be prostituted for this villainy are too naive to understand the complexity of the issues.

Who Benefits from Televised Political Advertising?
There are other arguments for and against the increasing use of televised advertising in political campaigns that are subtle variations of the above themes. In general however, the argument for the use of television political advertising consists of the view that: 
1. it is consistent with the notion of free and robust political speech;

2. it is in consonance with the contemporary corporate strategy approach to the management of political campaigns especially because,

3. it provides a medium which offers to voters a unique set of advantages not present in other channels of communication.

In contrast, the argument against the increasing use of televised political advertising basically consists of the following elements:

1. The use of TV advertising, particularly 30 -second spot television commercials, results in the substitution of images or candidate style for the substance of important campaign issues;

2. Television advertising has increasingly degenerated into negative advertising which is arguably unethical;

3. The increased incidence of television advertising, particularly when charged with emotionalism and negativism, has contributed to lower voter turnout and perhaps to a less informed voter;

4. Political advertising casts doubts upon the professional and ethical behavior of all marketing professionals involved in the political support process.

On balance then, is the prominence of televised political advertising a development worth nurturing? The answer probably turns a great deal on one's assessment of costs and benefits of TV political advertising which are discussed in the above paragraphs. Certainly there are advantages to the practice. It is good for some. The question is: for whom is it good?

Given the growth in its utilization, a number of political candidates have obviously found television advertising, especially negative advertising which attacks the opponent, to be a useful strategy. For instance, it appears that nonincumbents who have no record of their own to feature find it tempting and perhaps efficient to use television to tear down the record of their incumbent opponents [Diamond and Bates 1984]. Some voters may also find it useful to have the most questionable aspects of a candidate's record or character uncovered in this fashion. Similarly, certain segments of the ad industry have also found the growth of political advertising expenditures a lucrative development. However, as pointed out by Hill [1984], many large ad agencies have also shied away from political campaigns for fear of offending their existing sponsors, nonpayment, and other reasons. This has resulted in the ascendence of another group, called political consultants, to fill the vacuum left by the ad agencies who have not chosen to pursue this growth. Sorenson [1984] writes of this trend as follows:

Today choosing policy advisors is insignificant compared to lining up the right pollster, media adviser, direct mail operator, fund-raiser and makeup artist. Today's public positions are not comprehensively articulated but condensed into bumpersticker slogans and clever TV debate ripostes that will please everyone and offend no one (p.46).

Television stations too are beneficiaries of the political advertising process as they increase their ad revenues but, given the periodic nature of campaigns, these incomes are a very cyclical source of revenue. Also, as discussed above, voters seem to have mixed reactions to televised political advertising, although the recent increase in negative advertising has stimulated some surprisingly harsh reaction in certain circles. For example, after a particularly nasty and intense 1986 Senatorial campaign characterized by many negative political TV commercials, a poll of 604 South Dakota voters showed that 33 percent would like limits on political advertising and 61 percent would actually favor banning political ads on television by replacing them with additional candidate debates. [Fialka 1986].

The answers to all of these questions concerning political TV advertising are elusive. The nature of the process being discussed is complex. Yet it appears fairly 
certain that, because of the controversy being caused by political televised advertising and its prominence in the U.S. election system, some steps will be taken to modify the process. It remains to be seen whether forthcoming attempts to regulate political advertising as envisioned by Senators Danforth (R.-Mo.) and Boren (D.-Ok.) will be successful, and whether they will have any spillover effect for the regulation of commercial advertising.

Research Questions and Political Advertising

Public Policy Options to Adjusting Political Advertising on TV

Option A: Federally funded broadcast advertising
It would obviously be beneficial if future policy decisions were based on as much information as possible. To that end, Table 1 presents a list of important research questions related to the general issue of televised political advertising. Basically, an examination of the Table indicates that substantial information should be gathered before forming any definitive judgments about the process and impact of televised political ads. A review of the Table suggests that many of the research questions about televised political advertising which are suggested for additional analysis reflect the considerations about this issue which have been developed in the above paragraphs. For examples, topics 5 and 8 , dealing with interaction between political TV advertising and voter information and participation strike at the heart of the issue and will likely require many studies and multiple settings. In addition, some tentative data bases of information as well as possible methodologies are put forward in Table 1 in an attempt to help set a very preliminary agenda of research for this area and to provide further thought on the topic from an empirical standpoint. While it is always difficult to stipulate a priority of completion to be associated with a particular research agenda, certainly the research questions reflected in topics 1,3 , and 6 of Table 1 are less imposing, and therefore more doable, than, for instance, the more theoretical issues reflected in topics 4,7 , and 10 . The outcomes of any valid empirical research will have a bearing on topics 2 and 9 , which deal with the more subjective areas of ethics and the regulation of political advertising on TV. If possible, research efforts also ought to be based upon or at least related to the communication theories which have already been developed in various disciplines. Appendix A provides our succinct analysis of the applicability of current communications models to the issue of political television advertising. The present state of affairs is such that any well-done empirical work will obviously give additional weight to the "pro" or "con" side of the political advertising debate.

Some of the specific public policy proposals which have been put forward in the media are briefly articulated in the section below. Implicit in a number of these suggestions is the realization that the equal time provision of Section 315 of the FCC Act would have to be amended to limit free television time to only "major" candidates. Also a strict interpretation of the First Amendment could be fatal to most of these options. These options are not all mutually exclusive and therefore some of them could be used in combination with each other.

This option reported in a recent New York Times article [Taylor 1987], was a recommendation of the prestigious Committee on the Constitutional System. It suggests that a public fund be created to underwrite the broadcast advertising undertaken by the nominees of major parties for major federal positions (President, Senate, and Congress). This proposal would include the stipulation that no other money be spent for broadcast advertising. In addition, in order to strengthen party discipline, half of the money would go to the party leaders in Congress who could allocate it as they so chose among the parties' nominees. The advantage of this approach is that it would alleviate the influence of PAC (Political Action Committee) spending upon political campaigns and would tend to equalize the amount spent on 
broadcast advertising by each of the nominees of the major parties. On balance, it would also probably reduce the absolute amount of dollars spent on broadcast advertising in general and TV advertising in particular. An obvious disadvantage, of course, is that the strategy would require the use of tax dollars or other federal revenues and might possibly reduce the flow of information about candidates to the public. Another disadvantage is that this proposal would tend to equalize the amount of money spent by both incumbents and challengers. Increasingly, incumbents are able to attract larger sums of campaign funding than are challengers and for this reason, sitting members of Congress may see this option as generating the loss of an important tactical advantage [Fialka 1987].

Option B: The regulation of

Several legislative proposals have come before the Congress during the past three advertising style model

terms which sought to control the style of political TV ads while not restricting content. Recent legislative proposals include requirements for so-called "tombstone" or "talking head" ads by candidates without allowing animation or dramatic film variations. According to Senator Robert Kasten (R., WI), an upcoming Congressional bill reportedly will propose that candidates appear in all their TV ads [private interview, Jan. 30, 1987].

Option C: The "Time equals Substance" Model

Option D: A National Political Advertising Review Board (the NPARB Model)

Option E: The LincolnDouglas Model
This approach suggested by Kaid and Sanders [1978] and others suggests that political TV commercials must be over 120 seconds in length. The idea is that it is difficult to sustain an emotional, nonfactual appeal or an unsubstantiated attack on one's opponent for that length of time without considerable documentation of charges. Whether the rationale behind this option is correct remains to be determined. To complicate matters further, television stations are presently reluctant to grant such blocks of advertising time because of the disruption to their commercial programming. Moreover, political advertising consultants are not at all convinced that longer commercials are any more effective than shorter commercials in terms of generating recall or favorable attitudes.

This approach suggests that television political advertising is an acceptable method of communicating with the public as long as it is not unethical, misleading, deceptive, or unfair in its approach. Because of First Amendment safeguards to the right of unfettered political speech, this option suggests a voluntary, regulatory group that might be established which would operate like the National Advertising Review Board of the Better Business Bureau. This board would screen political advertisements for general ethical propriety. In other words, it would ban or at minimum publicize campaign commercials that are thought to be unfair, unethical, misleading, or deceptive. Caywood and Laczniak [1985] have suggested how the mechanics of such an approach might work when mutually embraced by the candidates involved in a major political campaign. The Fair Campaign Practices committee which ceased operations in the 1970s offered services to arbitrate such disputes. More recently, suggestions by the American Association of Advertising Agencies for political candidates to develop such procedures were not well received during the 1986 pre-campaign period.

Named in honor of the famous Lincoln and Douglas debates, this model proposes that each candidate be required to purchase advertising time in 90 second blocks. During the first 60 seconds they would be permitted to put forth whatever televised political message they wished. However, prior to screening they would have to turn that commercial over to their opponent who would be allowed 10 days to develop a 30 -second rebuttal. This approach, advocated in the academic literature by Szybillo and Hartenbaum [1976], among others, is grounded in the fundamental premise that the purpose behind effective television political advertising-from the stand- 
point of the public-is to promote political debate. Presumably the Lincoln-Douglas format would encourage a sifting and winnowing of the issues among voters. Many observers currently feel that the growth of TV advertising has made the media more alert and more likely to challenge statements put forward in TV spots [Taylor 1986]. The mechanics and timing of coordinating such an information exchange about candidate advertising campaigns would include some obvious obstacles. One interesting variation of this alternative was also proposed to Congress in $1983[\mathrm{H}$ 2490 ] and involved granting federally funded candidates free broadcast time when these candidates had been attacked in a political TV ad by an opponent. Serious questions of what constitutes an "attack," issues of Constitutionality, and the low likelihood of network cooperation no doubt contributed to this bill's quick demise.

Option F: The United Kingdom Model

Option G: The Brazilian Variation

Option H: The Australian Model

Commentary Concerning the Options
So named because the proposal is similar to the mechanism used during elections in the United Kingdom, this option involves strict limits on the amount of TV political advertising that each candidate could purchase. In lieu of the limited advertising time available, each of the major networks would make available certain slots of time, perhaps 10-15 minutes, for several weeks prior to the campaign. The major parties and their candidates would be allowed to present their political platforms. These slots would be provided during prime time viewing and the political commercials/presentations would appear simultaneously on all of the major networks. The obvious advantage is that by providing such extended periods of time, the complexity of various issues could be more fully explored. The disadvantage, of course, is that the populace has an option to watch another nonnetwork television channel, switch to cable, turn on their VCR, or employ any of a number of other basic mechanisms which would make defeating the impact of this option easier than simply avoiding the standard 30-second spot television commercial. Most political consultants feel that this approach, in terms of viewership, would be rather dismal.

This approach is similar to the UK model approach except it is more severe in its requirements. In the weeks prior to the campaign, major parties in the election process would be given control over network programming for a certain amount of prime time each day, perhaps one hour. All other broadcast advertising would no longer be permitted. This approach has been recommended by historian Arthur Schlesinger [1986] and others. Advantages and disadvantages of this approach are similar to those discussed regarding the UK model.

This approach requires that there be a 72-hour cooling-off period from televised political advertising and other broadcast advertising of any sort prior to the Australian votership going to the polls. The idea is that these final hours should be used by the voters themselves to discuss the issues that have been presented thus far. It also mitigates the possibility of last-minute charges being raised by a candidate through political advertising without the opponent's having the benefit of rebutting these charges prior to the election.

Exactly which of the above options will most likely occur is a matter of considerable speculation. Some variation of options A and B would have the highest likelihood of making it out of Congressional committees in the near future. Yet, if one subscribes to a strict constructionist view of the First Amendment, all but voluntary agreements among candidates (Option D) might be struck down by the Courts as unconstitutional if implemented via legislation. Even voluntary agreements may be subject to criticism or challenge by one of the consenting parties if a campaign unfolds in an unsatisfactory manner. Perhaps the natural course of events will lessen the reliance of candidates upon political television advertising - at least the variety which is negative or highly emotionally charged. Today's higher standards 
of accountability for political candidates, partly reflected in the Hart-Rice fiasco, may make it more difficult for all candidates, including the one initiating the advertising, to use the more controversial forms of promotion. On balance however, we project a continuation of high profile discussions of the pros and cons of political advertising. And for the near term, we see the continued protection of political advertising as a unique form of twentieth century free speech.

Conclusion Given the events of recent elections, it seems destined that the discussion concerning the regulation of televised political advertising will become more heated. For example, looking to the 1988 presidential elections, Democratic National chairman Paul Kirk is seeking to impose a voluntary code of conduct among Democratic aspirants whereby they would refrain from negative advertising. Such negative advertising is seen as damaging to party unity and both Rep. Richard Gephart of Missouri and former Gov. Bruce Babbitt of Arizona have embraced this position [Shribman 1987].

In general, however, mainly because of First Amendment considerations, the Supreme Court and other federal courts have steadfastly preserved an unstructured communication process regarding political advertising. But, neoclassical liberals are more interventionist in their approach to the public policy of advertising [Rotzoll and Haefner 1986]. They have wondered aloud how it is that what we say about a can of hair spray, a package of gum, or any other consumer product can be strictly regulated while what is said in the course of a political campaign remains unconstrained. From society's standpoint, it is far better to be fooled into buying a vegetable slicer or other consumer products because of false advertising than it is to cast one's vote on the basis of TV ads for a presidential candidate who ultimately has the power to end life on this planet. In any event, the debate continues. It would be useful to begin upon the research agenda suggested in Table 1 of this paper and to include in those investigations some of the variables that have been identified here because they reflect the costs and benefits of adjusting the increasingly influential process of televised political advertising.

Appendix A A Note Concerning the Theoretical Underpinnings of the Political Advertising Debate
The major existing frameworks in communications theory were reviewed in order to uncover a paradigm which would be helpful in putting the controversy of televised political advertising into perspective. An examination of the available theory-based models in marketing, advertising, and communications research leads to the conclusion that they all seem currently inadequate to provide a comprehensive foundation for political advertising research because they do not encompass the key variables essential to the controversy. For example, the famous "encode-decode" model of Schramm and Roberts [1971] and other adaptations of the seminal work [Engel, Warshaw, and Kinnear 1986] fail to reflect the critical legal, social, and political institution variables which influence the data surrounding political advertising.

The somewhat more complex social system models of mass communications [DeFleur and Ball-Rokeach 1975] capture elements of the debate but would require significant reinterpretation and refinement to help researchers clarify the issues of political advertising. For instance, several of the key distinctions between political and commercial advertising as well as voter versus general receiver behavior are not depicted. Boddewyn's model [1985] of advertising self-regulation includes many of the social institutions involved with political advertising, but its focus is too narrow for the breadth of the political advertising issue.

Other models of communications theory including coorientation [Chaffee 1972, Broom 1978], uses and gratifications [Kline 1972], psychodynamic approaches [Packard 1957], sociocultural models [Lewin 1958] and so on, while partly useful, do not anticipate the multidimensional qualities of the political advertising controversy. Marketing models of consumer behavior [Nicosia 1966; Howard and Sheth 1969; and Engel and Blackwell 1982] are neither communications-based nor strongly linked to the institutional constraints on political action. These models, however, may be useful for more micro-oriented considerations involving the effects of political advertising in particular campaigns. General advertising and society models such as Rotzoll and Haefner [1986] perhaps come closest to providing a 
framework for understanding the political advertising debate. However this particular model fails the general test of parsimony and clarity as it becomes bogged down in the libertarian versus neo-liberal approaches to regulation and institutional control.

Perhaps one of the more creative efforts in this area is the work of Newman and Sheth [1985] and their formulation of a model of voter behavior. Their seven-factor model may eventually be developed to the point where it can fully encompass the effect of TV political advertising within the context of other significant factors in a political campaign. At present, however, its emphasis is micro- in nature and its application is geared toward uses which identify voter beliefs about salient issues and subsequent choice likelihoods in the setting of primary elections.

In general, our brief review of existing communications models finds such shortcomings as a lack of: normative guidelines, predictive capability, rich concepts, and relevant ideas when one attempts to apply the models to TV political advertising. Thus, communications marketing and advertising models are either too abstract at the high theory level or too narrow to include the complex texture of variables found in the web of political advertising. Efforts to build a middle-range theory are necessary before empirical research can most efficiently guide policy developments.

\section{References}

Arterton, F. Christopher (1984), Media Politics-The News Strategies of Presidential Campaigns. Massachusetts: Lexington Books.

Atkin, Charles K., Lawrence Bowen, Oguz B. Nayman, and Kenneth G. Sheinkopf (1973), "Quality Versus Quantity in Televised Political Ads," Public Opinion Quarterly 37 (Spring), 209-24.

Atkin, Charles K. and Gary Heald (1976), "Effects of Political Advertising," Public Opinion Quarterly 40 (Summer), 216-28.

Blumenthal, Sidney (1980), The Permanent Campaign. New York: Simon and Schuster. (1981), "Marketing the President," New York Times Magazine, (Sept. 13), 435.

Boddewyn, J.J. (1985), "Advertising Self-Regulation: Private Government and Agent of Public Policy," Journal of Public Policy and Marketing 4, 129-42.

Bowers, J.A. (1972), "Issues and Personality Information in Newspaper Political Advertising," Jourmalism Quarterly 49, no. 3, 552-56.

(1973), "Newspaper Political Advertising and Agenda Setting Function," Jourmalism Quarterly 50 , no. 3, 552-56.

Broom, Glen M. (1978), "Coorientational Measurement of Public Issues," Public Relations Review (Winter), 110-19.

Caywood, Clarke L. and Gene R. Laczniak (1985), “Unethical Political Advertising: Decision Considerations for Policy and Evaluation," in Marketing Communications-Theory and Research, Michael J. Houston and Richard J. Lutz, eds. AMA Proceedings Series, 37-41.

Chaffee, Steven H. (1972), "The Interpersonal Context of Communications," in Current Perspectives in Mass Communication Research, F. Gerald Kline and Phillip J. Tichenon eds. California: Sage.

(1980), “Mass Media Effects-New Research Perspective," Mass Communication Review Yearbook. California: Sage, 77-101.

Colford, Steven W. (1985), "No Ad Curbs: . . ., " Advertising Age (Dec. 2).

(1986), "Pols Accentuated Negative," Advertising Age (Nov. 10), 3.

DeFleur, Melvin L. and Sandra Ball-Rokeach (1975), Theories of Mass Communications. New York: David McKay Company.

DeVries, Walter (1975), "Taking the Voter's Pulse," in The Political Image Merchants' Strategies for the Seventies. Ray E. Hiebert, ed. Washington D.C.: Acropolis Books.

Diamond, Edwin and Stephen Bates (1984), The Spot: The Rise of Political Advertising on Television. Massachusetts: The MIT Press.

Elebash, Camille and James Rosene (1982), "Issues in Political Advertising in a Deep South Gubernatorial Race," Journalism Quarterly 59 (Autumn), 420-23. 
Engel, James F. and Roger D. Blackwell (1982), Consumer Behavior, Fourth ed., Illinois: Dryden Press.

Engel, James F., Martin R. Warshaw, and Thomas C. Kinnear (1986), Promotional Strategy, 6th ed. Homewood, Ill.: Richard D. Irwin.

Faber, Ronald J. and M. Claire Storey (1984), "Recall of Information From Political Advertising," Journal of Advertising 13, no. 3, 39-44.

Farney, Dennis (1986), "Victor in Nasty Texas Governor's Race . . .," The Wall Street Journal (Oct. 27), 52.

Fialka, John J. (1986), "Intense Mudslinging in South Dakota . . .," The Wall Street Jourmal (Nov. 15), 60.

(1987), "House Incumbents . . . ," The Wall Street Journal (April 8), 58.

Garramone, Gina M. (1984), "Voter Responses to Negative Political Ads," Journalism Quarterly 61 (Summer), 250-59.

Graber, Dorothy (1976), "Effects of Incumbency in Covering Patterns in 1972 Presidential Campaigns," Journalism Quarterly 53, no. 3, 497-508.

(1980), Mass Media and American Politics. Washington D.C.: Congressional Quarterly Press.

Hill, David B. (1984), "Political Campaigns and Madison Avenue: A Wavering Partnership," Journal of Advertising 13, no. 3, 21-26, 58.

Hofstetter, Richard C. and Cliff Zurkin (1979), "TV Network News and Advertising in the Nixon and McGovern Campaigns," Journalism Quarterly 56 (Spring), 106-15.

House Bill 2490 (1983), 96th Congress, 2d. Session.

House Bill 5307 (1985), 98th Congress, 2nd Session.

Howard, John A. and Jagdish N. Sheth (1969), The Theory of Buyer Behavior. New York: John Wiley and Sons.

Humke, Ronald G., Raymond L. Schmitt and Stanley E. Gupp (1975), "Candidates, Issues and Party in Newspaper Political Advertisements," Journalism Quarterly 49 no. 3, 499-504.

Jacobson, Gary C. (1978), "The Effects of Campaign Spending in Congressional Elections," The American Political Science Review 36, no. 3, 157-70.

Joslyn, Richard A. (1980), “The Content of Political Spot Ads," Journalism Quarterly 57 (Spring), 92-98.

Kasten, Robert (1987), U.S. Senator (R. WI), Interview with author (Jan. 30), Madison, Wisconsin.

Kaid, Lynda Lee (1976), "Measure of Political Advertising," Journal of Advertising Research 16 (Oct.), 49-53.

and Keith R. Sanders (1978), "Political Television Commercials . . , " Communication Research. 5 , no. $1,57-70$.

Katz, Jeffrey L. (1986), "Negative Attacks Cited in Lower Senate Voting," The Milwaukee Journal (Nov. 6), 1, 19A.

Kline, F. Gerald (1972), "Theory in Mass Communication Research," in Current Perspectives in Mass Communication Research, F.G. Kline and P.J. Tichenor eds. California: Sage.

Laczniak, Gene R., Robert F. Lusch and Patrick E. Murphy (1979), "Social Marketing: Its Ethical Dimensions," Journal of Marketing 43 (Spring), 29-36.

Laczniak, Gene R., Robert F. Lusch and William A. Strang (1981), "Ethical Marketing: Perceptions of Economic Goods and Social Problems," Journal of Macromarketing 1 (Spring), 49-57.

Latimer, Margaret K. (1985), "Political Advertising for Federal and State Elections: Images or Substance?” Journalism Quarterly 62 (Winter), 861-68.

Lewin, Kurt (1958), "Group Decision and Social Change," in Readings in Social Psychology, Eleanor Maccoby et al., eds. New York: Henry Holt.

McCombs, Maxwell F. and Donald I. Shaw (1972), "The Agenda-Setting Function of Mass Media," Public Opinion Quarterly 36 (Summer), 176-87.

Meadow, Robert G. and Lee Sigelman (1982), "Some Effects and Noneffects of Campaign Commercials: An Experimental Study," Political Behavior 4, no. 2, 163-75.

Merritt, Sharyne (1984), "Negative Political Advertising: Some Empirical Findings," Journal of Advertising 13 , no. 3, 27-38.

Mills v. Alabama (1966), 384 U.S. 214, 16 L. Ed. 2d 484, 565. Ct. 1434, 1 Media L.R. 1334. 
Mulder, Ronald (1979), "The Effects of Televised Political Ads in the 1975 Chicago Mayoral Election," Journalism Quarterly 56 (Summer), 336-40.

Newman, Bruce I. and Jagdiah N. Sheth (1985), "A Model of Primary Voter Behavior," Journal of Consumer Research 12 (Sept.), 178-87.

Nicosia, Francesco M. (1966), Decision Processes: Marketing and Advertising Implications, New Jersey: Prentice-Hall.

Ogilvy, David (1983), Ogilvy on Advertising. New York: Vintage Books, 213.

O’Keefe, Garrett J. (1980), "Political Malaise and Reliance on Media," Journalism Quarterly 57 (Spring), 122-28.

O'Leary/Kamber Report, "Negative Campaign Advertising: Pro and Con," 1 (5).

Packard, Vance (1957), The Hidden Persuaders. New York: D.D. McKay Company.

Palda, K.S., (1975), "The Effect of Expenditure in Political Science," Journal of Law and Economics, (Dec.), 745-71.

Patterson, Thomas E. and Robert D. McClure (1973), Political Advertising: Voter Reaction to Televised Political Commercials. New Jersey: Citizens' Research Foundation.

Postal v. Schwartz, (1976), 423 U.S. 1041, 46 L. Ed. 2d 630, 965. Ct. 763.

Reid, Leonard N. and Lawrence C. Soley (1983), "Promotional Spending Effects in High Involvement Elections: An Examination of the Voter Involvement Explanation," Jourmal of Advertising 12, no. 2, 43-50.

Reston, James (1986), “Campaign '86 was a Disgrace to Democracy . . . ," The Milwaukee Journal (Nov. 6), 21A.

Roberts, Steven V. (1986), "Politicking Goes High-Tech," The New York Times Magazine (Nov. 22), 38.

Rothschild, Michael L. (1978), "Political Advertising: A Neglected Policy Issue in Marketing," Journal of Marketing Research 15, no. 1, 58-71.

Rotzoll, Kim B. and James E. Haefner (1986), Advertising in Contemporary Society. Cincinnati: SouthWestern Publishing Co..

Rust, Ronald T., Mukesh Bajaj, and George Haley (1984), "Efficient and Inefficient Media for Political Campaign Advertising," Journal of Advertising, 13, no. 3, 45-49.

Sabato, Larry J. (1981), The Rise of Political Consultants. New York: Basic Books, Inc.

Schlesinger, Arthur Jr. (1986), "Election Aftermath: Money and Meaning," The Wall Street Journal (Nov. 18), 36.

Schramm, Wilber L. and Donald P. Roberts (1971), The Process and Effects of Mass Communication. New York: Random House.

Senate Bill 2509 (1985), 98th Congress, 2nd Session.

Shribman, David (1987), "Conduct Code Barring Party Bashing . . . "The Wall Street Journal (March 12), 62.

(1986), “Costly Negative Congressional Campaigns . . ., " The Wall Street Journal (Nov. 7), 50.

Soley, Lawrence C. and Leonard N. Reid (1982), "Promotional Expenditures in U.S. Congressional Elections," Journal of Marketing and Public Policy 1, 147-55.

Sorenson, Theodore C. (1984), A Different Kind of Presidency. New York: Harper and Row.

Surlin, Stuart and Thomas F. Gordon (1976), "Selective Exposure and Retention of Political Advertising," Journal of Advertising 1, 32-37, 44.

(1977), "How Values Affect Attitudes Toward Direct Reference Political Advertising," Journalism Quarterly 54 (Spring), 89-98.

Szybillo, George J. and Ronald F. Hartenbaum (1976), "Political Advertising and the Broadcast Media," Journal of Advertising 5, no. 4, 42-46.

Taylor, Paul (1986), "Accentuating the Negative . . ., "The Washington Post National Weekly Edition, (Oct. 20), 6-8. 38.

(1985), “Incumbents Take Negative View of Election Ads," The Milwaukee Journal, (Nov. 28),

Taylor, Stuart Jr. (1987), “Citing Chronic Deadlock, Panel Urges Altering Political Structure,” The New York Times, (Jan. 11), 1, 10. 
The Wall Street Journal (1986), "Voter Turnout of 37.3\% was the lowest since 1942," (Nov. 6), 19. Tribe, Laurence H. (1978), American Constitutional Law. New York: The Foundation Press, Inc. USA Today (1986), “Garvey Outspent, Undaunted,” (Nov. 6), 2C.

Vanasco v. Schwartz, (1974, CA2 NY) 506 F2d 524, on remand Vanasco v. Schwartz, (1975, ED NY) 401 F. Supp. 87, affd. Schwartz v. Vanasco, (1976), 423 U.S. 1041, 46 L. Ed. 2d 630;, 96 S. Ct. 763, and affd. Schwartz v. Postal, (1976), 423 U.S. 1041, 46 L. Ed. 2d 630, 96 S.Ct. 763.

Wilson v. Superior Court of Los Angeles County, 13 Cal. 3d 652119 Cal. Rptrs 468532 P.2d 166 (1976). 